\title{
PENGARUH MODEL PROBLEM-BASED LEARNING TERHADAP KEMAMPUAN PEMECAHAN MASALAH GEOGRAFI SMA
}

\author{
Diyas Age Larasati ${ }^{1}$ \\ 1 Universitas Wijaya Kusuma Surabaya \\ Dukuh Kupang XXV No. 54 Surabaya \\ E-mail: larasati_age@yahoo.co.id
}

\begin{abstract}
Abstrak
Penelitian ini bertujuan menguji pengaruh model PBL terhadap kemampuan pemecahan masalah geografi SMA. Penelitian dilakukan di SMA Negeri 1 Sooko tahun ajaran 2015/2016. Subjek penelitian merupakan siswa kelas XI IPS 2 dan 3. Penelitian ini merupakan penelitian eksperimen semu (quasi experiment) dengan desain Non Equivalent Control Group Design. Berdasarkan selisih nilai pre test dan post test, ratarata gain score kemampuan pemecahan masalah geografi SMA kelas eksperimen lebih tinggi dengan skor 27,26 dibandingkan dengan kelas kontrol dengan skor 11,88. Hasil perhitungan analisis uji t menggunakan independen sample $t$ test diperoleh data p-level lebih kecil dari 0,05 (p<0,05) yaitu 0,00. Hasil perhitungan ini membuktikan bahwa model PBL berpengaruh terhadap kemampuan pemecahan masalah geografi SMA. Jadi, dapat disimpulkan bahwa model PBL berpengaruh terhadap kemampuan pemecahan masalah geografi SMAN 1 Sooko.
\end{abstract}

Kata Kunci: Model Problem Based Learning, Kemampuan Pemecahan Masalah

\begin{abstract}
The purpose of this study was to clarify the effect of the PBL model of problem-solving ability. This study do in SMA Negeri 1 Sooko 2015/2016. Study of the subject is the student of class XI IPS 2 dan 3. Form of quasi-experimental research design with non equivalent design control group. Subjects were selected based on the value of Middle Exam School (UTS) semester who have the same average (homogeneous). Control using a model class lectures and discussions, while the experimental class using PBL models. Gain score Data were analyzed using independent sample T-test Test with the help of the computer program SPSS 16.0 for Windows. Gainscore learning using PBL model of higher than conventional. The average value of the experiment gainscore class of 27, 26 and 11.88 of control. The results of the analysis of the Independent Sample T-Test Test, the difference shows a p-value of 0.000 level. The level of $p$-value less than $0.05(P<0.05)$. The results of this study there was a significant effect PBL models to the problem-solving abilities. So the conclusion "PBL model significantly influential to the high school geography problem solving skills in SMAN 1 Sooko".
\end{abstract}

Key Words: models of PBL, problem-solving abilities

\section{PENDAHULUAN}

Model Problem Based Learning (PBL)

adalah langkah-langkah pembelajaran berdasarkan masalah nyata. Masalah nyata akan memotivasi siswa untuk mengembangkan kemampuan berpikir tinggi. Hal tersebut sejalan dengan pendapat Nur
(2008) Model PBL merupakan model pembelajaran yang mengembangkan kemampuan berpikir tinggi dengan menghadirkan permasalahan-permasalahan nyata, mengajukan pertanyaanpertanyaan, dan memfasilitasi penyelidikan dan dialog. Langkah-langkah model 


\section{ge}

PBL lebih memfokuskan pembelajaran pada siswa dan memotivasinya untuk mengembangkan kemampuan berpikir tinggi, seperti kemampuan pemecahan masalah, berpikir kritis, dan kreatif.

Model PBL melatih siswa mengembangkan kemampuan berpikir tingkat tinggi. Hal tersebut sesuai dengan pendapat Arends (2008) dan Tresnaningsih (2009) Model PBL dirancang untuk membantu siswa mengembangkan kemampuan berpikir, kemampuan pemecahan masalah, dan kemampuan intelektualnya. Pendapat tersebut tepat, karena langkah-langkah dalam model PBL melatih siswa mengembangkan kemampuan berpikir yang dimilikinya.

Berdasarkan sejarah model PBL pertama kali dipelopori oleh Howard Barrows tahun 1960 di McMaster University di Hamilton, Ontario, Kanada. Model PBL awal mulanya hanya digunakan di bidang kedokteran saja. Siswa kedokteran pada saat itu mengalami kesulitan dalam mengingat dan rendahnya hasil belajar. Permasalahan tersebut diatasi dengan menggunakan model $P B L$ dan terbukti dapat meningkatkan hasil belajar serta daya ingatan siswa lebih panjang. Beberapa keberhasilan model $P B L$, membuat banyak peneliti menguji dan menerapkannya dalam berbagai ilmu. Hal tersebut sejalan dengan pendapat Hung (2008) Model PBL bisa digunakan di berbagai bidang ilmu khususnya pendi-dikan.

Lima karakteristik model $P B L$ menurut pendapat Arends (2008) dan Nur (2008), 1) Merumuskan masalah; 2) Berfokus pada interdisiplin; 3) Penyelidikan otentik; 4) Menghasilkan karya nyata dan memamerkan; 5) Kolaborasi. Pendapat yang disampaikan Arends dan Nur sudah tepat, karena model $P B L$ berpusat pada masalah nyata dan melatih siswa aktif dalam pembelajaran. Karakteristik model $P B L$ yakni mulai dari guru menyajikan masalah nyata ke dalam pembelajaran dalam bentuk pertanyaan. Siswa mengkaji dan memecahkannya dari berbagai aspek ilmu melalui proses
Available at http://jurnal.unimed.ac.id/2012/index.php/geo e-ISSN: 2549-7057 | p-ISSN: 2085-8167

penyelidikan otentik. Proses penyelidikan otentik bertujuan agar siswa mendapatkan pengalaman nyata dalam memecahkan masalah secara nyata.

Hasil temuan dari penyelidikan tersebut dipamerkan dengan mempresentasikan kepada siswa lainnya. Siswa satu dengan lainnya dapat bekerjasama dalam memecahkan masalah. Berdasarkan karakteristik model PBL lebih menekankan keterlibatan siswa dalam pembelajaran (student centered). Sejalan dengan pendapat Rusman (2012), Student centered merupakan salah satu ciri model $P B L$.

Keaktifan siswa dalam penerapan model PBL akan menumbuhkan karakter yang mandiri. Karakter mandiri muncul karena dalam model PBL siswa dilatih melakukan pembelajaran secara mandiri seperti penentuan masalah, mencari informasi dalam bentuk penyelidikan sampai solusi yang dipilih guna memecahkan masalah secara individu.

Model PBL tidak hanya dapat menumbuhkan karakter mandiri, tetapi juga sosial. Sejalan dengan pendapat Sumarmi (2012) Model PBL mengarahkan siswa menjadi pembelajar secara mandiri dan kelompok. Pendapat yang dikemukakan oleh Sumarmi benar, karena model $P B L$ tidak hanya mendorong siswa untuk belajar mandiri, tetapi juga kelompok. Setiap anggota kelompok melakukan penyelidikan secara mandiri terlebih dahulu. Hasil temuan mandiri tersebut didiskusikan dalam kelompok, kemudian melakukan penyelidikan lagi secara kelompok. Kelompok dalam model $P B L$ hanya terdiri dari 4-6 siswa.

Penyelidikan secara kelompok berfungsi untuk memutuskan solusi yang tepat dan ilmiah guna memecahkan masalah. Hasil penyelidikan secara kelompok disajikan dalam bentuk laporan dan dipresentasikan di depan kelas. Kegiatan siswa secara kelompok menumbuhkan rasa saling menghargai pendapat setiap individu.

Guru memiliki peranan dalam model PBL sebagai pembimbing dan fasili- 
tator. Menurut Arends (2008) dan Sumarmi (2012) Guru bertindak sebagai penyaji masalah, memberitahukan kepada siswa prosedur pembelajaran, pemberi petunjuk pada sumber belajar tambahan, pemberi opini, dan sebagai pebelajar juga. Pendapat Arends dan Sumarmi sudah tepat, karena tugas guru dalam model $P B L$ hanya membimbing siswa dalam proses penemuan solusi yang tepat dan ilmiah. Guru bertugas untuk memberitahukan kepada siswa prosedur pembelajaran dan membimbing siswa apabila mengalami kesulitan dalam penyelidikan. Guru juga memberikan petunjuk informasi sebagai sumber belajar tambahan tanpa memberi jawaban yang benar atau salah kepada siswa.

Model PBL memiliki beberapa keunggulan dibanding dengan model pembelajaran lainnya. Salah satu keunggulan model PBL menurut Trianto (2009), model PBL adalah lingkungan belajar yang mengaktifkan sebagian besar prinsip-prinsip yang dapat meningkatkan pembel-ajaran seperti aktif, bekerjasama, um-pan balik (feedback). Pendapat tersebut benar, karena sintak model PBL mendorong siswa untuk aktif dalam pembelajaran, bekerjasama dalam kelompoknya untuk mencari solusi yang tepat, serta terjadi umpan balik terhadap sesama siswa.

Keunggulan model $P B L$ lainnya menurut Borrows (2005), model PBL menawarkan kesempatan untuk berlatih mengembangkan kemampuan pemrosesan seperti pemecahan masalah, keterampilan tim, keterampilan belajar seumur hidup, keterampilan penilaian diri". Pendapat Barrow tepat, karena yang dinilai bukan hasil saja, tetapi proses pembelajaran yang dilakukan siswa dalam menemukan solusi tersebut.

Hal tersebut diperkuat lagi pendapat Arvyaty \& Cipto Saputra (2013), model PBL adalah belajar subjek pengetahuan dalam konteks menggunakan dan mengembangkan keterampilan proses. Model PBL lebih menekankan proses pembelajaran karena sintak-sintaknya mendorong siswa mengembangkan keterampilan proses. Sedangkan keunggulan model $P B L$ lainnya menurut Rusman (2009), model PBL memaksa siswa untuk belajar prinsip-prinsip dasar subjek yang dibutuhkan dalam konteks untuk memecahkan masalah".

Pendapat Rusman sudah tepat, karena model PBL memusatkan siswa pada masalah dan pembelajarannya menekankan pada keterampilan proses khususnya keterampilan memecahkan masalah. Hal tersebut diperkuat oleh pendapat Dasna (2005), model PBL berfungsi sebagai media untuk membangun kecakapan berpikir tingkat tinggi/ high order thingking skill (HOTS) seperti kemampuan berpikir kritis, kreatif, dan pemecahan masalah.

Kemampuan berpikir tingkat tinggi diperoleh dari pelaksanaan sintak-sintak pembelajaran yang ada didalam model PBL. Lima sintak pembelajaran model $P B L$ menurut Arends (2008), 1) Memberikan orientasi permasalahan pada siswa; 2) mengorganisasikan siswa untuk meneliti; 3) membantu investigasi mandiri dan kelompok; 4) mengembangkan dan mempresentasikan hasil temuan dari penyelidikan; dan 5) menganalisis dan mengevaluasi proses mengatasi masalah. Kelima sintak dalam model $P B L$ mendorong siswa untuk mengembangkan kemampuan berpikir khususnya kemampuan pemecahan masalah.

Penelitian terdahulu yang dilakukan oleh Tamri (2012), ada pengaruh model $P B L$ terhadap kemampuan pemecahan masalah. Hasil penelitian Tamri menunjukkan bahwa rata-rata nilai kelas $P B L$ sebesar 71,1 , kelas $S T A D$ sebesar 64,3, dan kelas integrasi $P B L$ dan $S T A D$ sebesar 65,7. Ber-dasarkan nilai rata-rata tersebut menunjukkan bahwa model $P B L$ memiliki rata-rata nilai paling tinggi dibandingkan dengan model STAD dan intergasi $P B L$ dan STAD. Penelitian tersebut terbukti bahwa model $P B L$ 


\section{gé grati}

berpengaruh terhadap kemampuan pemecahan masalah.

Hal tersebut diperkuat lagi oleh penelitian Arvyaty dan Cipto Saputro (2013), model PBL merupakan model pembelajaran yang dapat meningkatkan kemampuan pemecahan masalah Penelitian yang dilakukan Arvyaty dan Cipto Saputro telah membuktikan bahwa model PBL dapat meningkatkan kemampuan pemecahan masalah, karena didukung oleh sintak pembelajarannya. Berbeda dengan penelitian Tamri dan Arvyaty dan Cipto Saputro, penelitian ini menerapkan model PBL pada mata pelajaran geografi. Berdasarkan observasi awal, guru geografi belum pernah menerapkan model PBL pada materi aspek kependudukan. Materi aspek kependudukan mengandung permasalahan nyata yang ada di sekitar siswa. masalah penduduk ada yang secara kuantitas maupun kualitas.

Permasalahan kependudukan merupakan masalah nyata yang berada dekat dengan siswa, dan terjadi sejak dahulu bahkan sampai sekarang masalah tersebut belum terpecahkan secara efektif. Tingkat kepadatan dan persebaran penduduk di Mojokerto belum merata, jika dilihat dari aspek kuantitas. Aspek kualitas seperti meningkatkan polusi air, tanah, maupun udara, kemacetan, dan pemukiman kumuh. Pemerintah baik pusat maupun daerah sudah menerapkan pro-gram untuk memecahkan masalah tersebut. Akan tetapi, masalah tersebut belum juga teratasi dengan baik.
Available at http://jurnal.unimed.ac.id/2012/index.php/geo e-ISSN: 2549-7057 | p-ISSN: 2085-8167

Adanya beberapa alasan di atas, maka perlu dilakukan eksperimen model PBL terhadap kemampuan pemecahan masalah. Hal tersebut bertujuan untuk mengetahui apakah model PBL berpengaruh terhadap kemampuan pemecahan masalah geografi SMA pada materi aspek kependudukan.

\section{METODE PENELITIAN}

Penelitian ini menggunakan rancangan penelitian Quasi Experiment. Desain penelitian ini menggunakan control group dengan dua kelompok yang memiliki kemampuan hampir sama (homogen) dijadikan sebagai kelompok eksperimen dan kontrol. Quasi Experiment digunakan karena peneliti tidak dapat mengendalikan kedua kelompok yang diteliti.

Desain ini menggunakan pre-test yang diberikan sebelum perlakuan dan post-test diberikan setelah perlakuan. Pemberian posttest berfungsi untuk mengetahui pengaruh perlakuan yang diberikan menyebabkan perubahan yang lebih baik. Pengaruh dari eksperimen dapat diketahui dengan cara membandingkan dengan kelompok kontrol.

Penelitian ini membandingkan kemampuan pemecahan masalah sebelum dan sesudah diberi perlakuan pada kelompok eksperimen dan kontrol. Desain yang digunakan dalam penelitian ini digambarkan dalam bentuk Tabel 1 berikut ini

Tabel 1 Desain Penelitian

\begin{tabular}{llll}
\hline Kelompok & Pretest & Perlakuan & Posttest \\
\hline Eksperimen & $\mathrm{O}_{1}$ & $\mathrm{X}$ & $\mathrm{O}_{2}$ \\
Kontrol & $\mathrm{O}_{1}$ & - & $\mathrm{O}_{2}$ \\
\hline
\end{tabular}

Sumber: Arikunto, 2006

Keterangan:

$\begin{array}{lll}\mathrm{X} & : \quad \text { Perlakuan dengan model Problem Based Learning } \\ - & : & \text { Tidak ada perlakuan atau pembelajaran dengan model }\end{array}$
ceramah dan diskusi kelompok 


\section{$\mathrm{O}_{1} \quad: \quad$ Pretest \\ $\mathrm{O}_{2} \quad$ : Posttest}

Berdasarkan rancangan penelitian ini menggunakan dua variabel, yaitu 1) variabel bebas yaitu model $P B L$, dan 2) variabel terikat berupa kemampuan pemecahan masalah. Subjek penelitian ini dipilih dua kelompok berdasarkan nilai Ujian Tengah Semester (UTS ) geografi semester ganjil yang homogen kemudian diundi dengan menggunakan mata uang logam. Kelompok eksperimen diberi perlakuan dengan mengguna-kan model $P B L$, sedangkan kelompok kontrol menggunakan model yang biasa digunakan guru (ceramah dan diskusi kelompok).

Bahan analisis penelitian ini adalah data gainscore yang diperoleh dari pengurangan terhadap kemampuan pemecahan masalah geografi SMA setelah dan sebelum perlakuan kegiatan pembelajaran diberikan. Teknik analisis hasil belajar yang di-gunakan adalah uji $\mathrm{t}$ sampel bebas (independent sampel $t$ test), yang di-lakukan melalui bantuan SPSS 16.0 for Windows pada nilai/taraf signifikansi $\alpha=$ 0,05 . Pedoman dalam pengambi-lan keputusan untuk independent sampel $t$ test yaitu:

Tabel 2 ata-rata Nilai Gain Score Kelas Kontrol dan Eksperimen

\begin{tabular}{llll} 
Kelas & Rata-rata & & \\
\cline { 2 - 4 } & Pretest & Posttest & Gainscore \\
\hline Kontrol & 50,31 & 62,19 & 11,88 \\
Eksperimen & 50,97 & 78,23 & 27,26 \\
\hline
\end{tabular}

Sumber: Hasil penelitian, 2016

Tabel 2 menunjukkan bahwa ratarata nilai kelas kontrol dan kelas eksperimen mengalami peningkatan setelah melaksanakan pembelajaran. Kelas kontrol mengalami peningkatan rata-rata nilai sebesar 11,88 poin yaitu dari 50,31 menjadi 62,19. Sedangkan nilai rata-rata pada kelas
- Jika nilai sig. atau signifikansi < 0,05 dan rata-rata hasil belajar kelas eksperimen lebih tinggi daripada kelas kontrol maka

- Jika nilai sig. atau signifikansi >0,05 dan rata-rata hasil belajar kelas eksperimen lebih rendah daripada kelas kontrol maka $\mathrm{H}_{0}$ diterima.

\section{HASIL DAN PEMBAHASAN}

Kemampuan pemecahan masalah geografi SMA yang digunakan dalam penelitian ini ditentukan berdasarkan selisih antara skor posttest dan pretest yang disebut gainscore. Gainscore diperoleh dengan cara mengurangi skor posttest dari masingmasing subjek dengan skor pretest. Gainscore tersebut menggambarkan kemampuan pemecahan masalah geografi SMA dari keseluruhan subjek, baik kelas kontrol maupun eksperimen. Gambaran nilai gainscore yang diperoleh berdasarkan selisih antara rata-rata posttest dan pretest dalam penelitian ini dapat dilihat pada tabel berikut. $\mathrm{H}_{0}$ ditolak. eksperimen mengalami peningkatan sebesar 27,26 poin, yaitu dari 50,97 menjadi 78,23 . Hasil ini menunjukkan bahwa antara kelas kontrol dan eksperimen terda-pat selisih rata-rata nilai gain score sebesar 15,38 . Selisih nilai rata-rata tersebut dapat dilihat pada diagram berikut. 


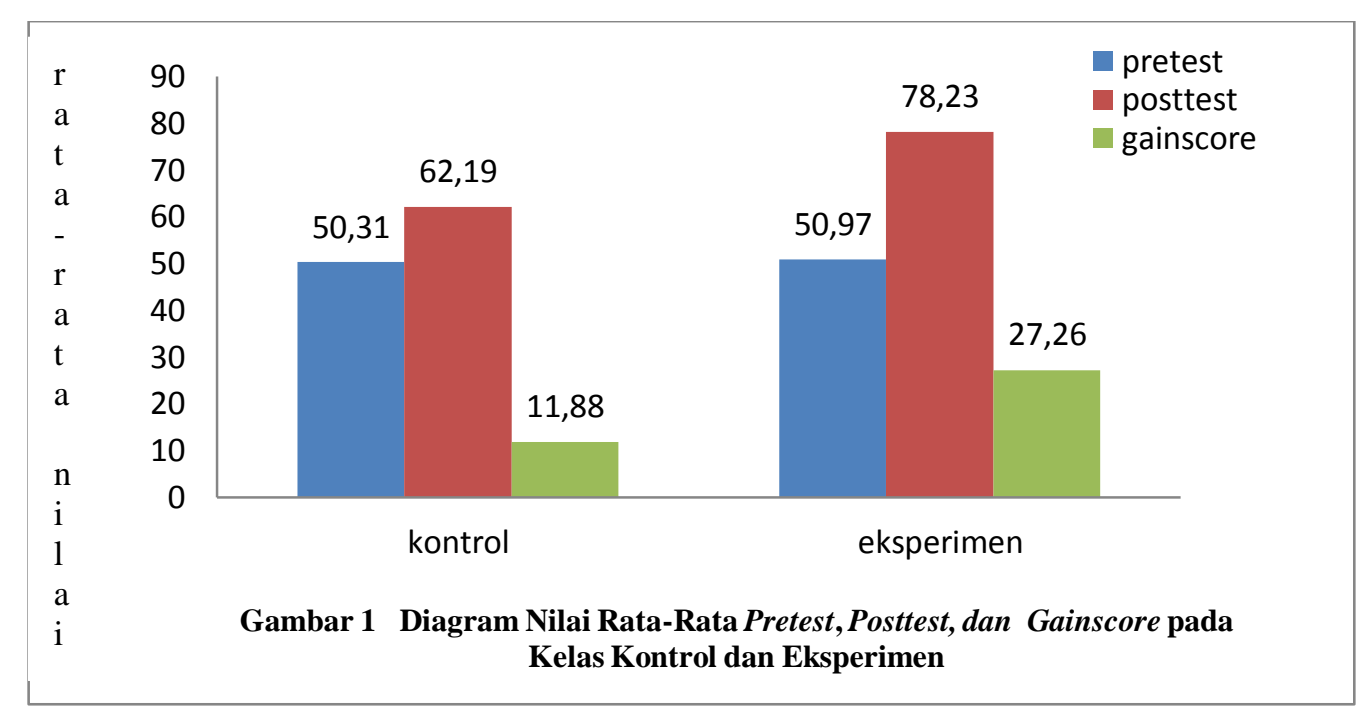

Hasil analisis data melalui uji formatbeda independent sample $t$ test menunjukkan angka signifikansi (sig.) 0,000. Apabila dilihat pada taraf kepercayaan 95\%, maka angka tersebut kurang dari 0,05 $(0,000<0,05)$. Ini berarti Ho (model ceramah dan diskusi kelompok tidak berpengaruh signifikan terhadap kemampuan pemecahan masalah geografi SMA) ditolak dan Hi (model PBL berpengaruh signifikan terhadap kemampuan pemecahan masalah geografi SMA) diteria. Ho tersebut ditolak dengan taraf kepercayaan $100 \%$. Kebenaran hipotesis ini dibuktikan dengan nilai rata-rata (mean) pada kelas eksperimen adalah 22.9032, lebih tinggi daripada kelas kontrol yaitu 11.0938.

Berdasarkan hasil uji $t$ menunjukkan bahwa pembelajaran geografi pada materi aspek kependudukan dengan menggunakan model $P B L$ berpengaruh signifikan terhadap ke-mampuan pemecahan masalah geografi SMA. Terdapat perbedaan antara kemampuan pemecahan masalah kelompok eksperimen dan kontrol. Siswa yang belajar dengan menggunakan model $P B L$ memiliki kemampuan pemecahan masalah geografi SMA lebih tinggi dibandingkan dengan model ceramah dan diskusi kelompok. Perubahan kemampuan tersebut dapat dilihat dari perbedaan rata-rata gainscore kemampuan sebelum perlakuan dan setelah perlakuan. Hasil penelitian ini didukung oleh penelitian sebelumnya yaitu penelitian yang dilakukan Ria (2009), Ratmanto (2011), Minarni (2012), dan Tamri (2012).

Pengaruh model $P B L$ terhadap kemampuan pemecahan masalah geografi SMA diduga kuat disebabkan oleh karaktristik model yaitu: 1) berorientasi pada masalah nyata; 2) penyelidikan nyata; dan 3) kerja sama. Ketiga karakteristik dari model $P B L$ diduga memiliki keunggulan mening-katkan tiap-tiap indikator kemampuan pemecahan masalah. Hal ini sejalan dengan pendapat Trianto (2009) bahwa "kemampuan pemecahan masalah diperoleh melalui proses pemusatan pada masalah nyata".

Pertama, Pembelajaran ini difungsikan sebagai tempat untuk memecahkan masalah secara nyata yang terjadi di lingkungan sekitar. Penyajian masalah secara nyata ke dalam pembelajaran dapat memberikan pengaruh pada pengembangan kemampuan masalah geografi SMA. Hal tersebut sejalan dengan pendapat Amir (2010) bahwa masalah memberikan peluang untuk meningkatkan motivasi dalam diri mahasiswa. Motivasi akan memicu siswa untuk mengembangkan pola berpikir terhadap permasalahan yang disajikan.

Pemberikan masalah dalam konteks nyata memberikan motivasi berupa tantangan bagi siswa untuk 
berpikir menemukan solusi yang efektif. Motivasi tersebut memicu siswa untuk mengembangkan kemampuan berpikirnya. Pengembangan kemampuan berpikir digunakan untuk mengkaji permasalahanpermasalahan yang menjadi tolak ukur keberhasilan model PBL dalam mencapai tu-juan penelitian ini.

Motivasi tumbuh karena setiap manusia memiliki rasa ingin tahu. Rasa ingin tahu ini memotivasi untuk secara aktif membangun pemahaman kognitif di dalam otak manusia. Hal tersebut sejalan dengan pendapat Sumarmi (2012), model $P B L$ membina pengembangan sikap penasaran/ingin tahu lebih jauh, berpikir objektif, mandiri, kritis, dan analitis baik seca-ra individu maupun kelompok.

Penelitian ini menggunakan masalah kependudukan baik secara kuantitas maupun kualitas yang terdapat di Kabupaten Mojokerto. Masalah kependudukan adalah fenomena yang terjadi sejak dahulu, bahkan sampai sekarang belum ada solusi yang efektif untuk mengatasi masa-lah tersebut. Hal tersebutlah yang akan menimbulkan menimbulkan rasa ingin tahu siswa. Rasa ingin tahu siswa terhadap masalah tersebut akan memotivasi siswa untuk menemukan pemecahan masalah yang efektif.

Kedua, selain kekuatan sebuah masalah sebagai landasan pengembangan model PBL yang dapat mempengaruhi kemampuan pemecahan masalah. Landasan kedua ini yaitu membimbing penyelidikan individual dan kelompok. Penyelidikan dalam penelitian ini adalah untuk mencari solusi masalah yaitu dengan merumuskan masalah, merumuskan hipotesis, mengumpulkan dan menganalisis informasi atau data, membuat kesimpulan terhadap permasalahan dan solusi yang diberikan, melakukan evaluasi terhadap kebijakankebijakan pemerintah atau instansi terkait terhadap permasalahan dan merekomendasikan solusi permasalahan kemudian memberikan alternatif langkah- langkah dalam mewujudkan solusi permasalahan.

Menurut Arends (2008) dan Tresnaningsih (2009), model PBL dirancang untuk membantu peserta didik mengembangkan kemampuan berpikir, memecahkan masalah, dan keterampilan intelektual. Pendapat keduanya tepat, karena langkah-langkah pembelajaran pada model $P B L$ di-rancang untuk memotivasi siswa mengembangkan kemampuan berpikir, memecahkan masalah, dan keteram-pilan intelektualnya. Hal tersebut diperkuat lagi oleh pendapat Arvyaty dan Cipto Saputra (2013), model $P B L$ dapat meningkatkan kemampuan memecahkan masalah siswa.

Model PBL juga menuntut sis-wa untuk menghasilkan produk tertentu dalam bentuk karya nyata. Karya nyata dalam penelitian ini berupa laporan yang disajikan dalam powerpoint berisi tentang hasil diskusi kelompok. Karya nyata tersebut kemudian dipresentasikan di depan kelas untuk dipertanggungjawabkan kepada siswa yang lain tentang apa yang telah dipelajari dan solusi apa yang diputuskan untuk mengatasi permasalahan.

Model PBL berpengaruh terhadap kemampuan pemecahan masalah tidak terlepas dari permasalahan yang diberikan. Setiap permasalahan yang diberikan secara tidak langsung membutuhkan rekomendasi berupa alternatif dalam pemecahannya. Hal tersebut dikarenakan siswa dituntut untuk memberikan alasan terhadap pemecahan permasalahan yang dipilih. Alasan ini bukan hanya berdasarkan pengalaman namun juga berdasarkan fakta-fakta yang terjadi. Semakin banyak rekomendasi pemecahan masalah yang dibuat, semakin sering siswa melatih kemampuan kemampuan pemecahan masalah terutama dalam hal menentukan alternatif pemecahan masalah.

Ketiga, landasan konsep yang ketiga yaitu bekerjasaama dalam kelompokkelompok kecil untuk saling berbagi 


\section{ge}

pengetahuan dan gagasan. Berbagi pengetahuan dan gagasan akan dapat meningkatkan pemahaman siswa terhadap permasalahan yang disajikan, memacu terbentuknya ide baru, dan memperkaya perkem-bangkan intelektual mahasiswa. Me-nurut Sudarman (2007), model PBL mendorong siswa untuk bekerjasama dalam kelompok guna menyelesaikan tugas. Model PBL menuntut siswa untuk bekerjasama dalam kelompok, sehingga menghasilkan keputusan solusi yang digunakan untuk mengatasi masalah.

Landasan yang ketiga yang melandasi model PBL adalah teori konstruktivistik. Teori ini memberikan peluang kepada siswa untuk mengkonstruksi pengetahuannya melalui pembelajaran yang berpusat pada siswa. Dalam hal ini, mahasiswa mengembangkan dan menggali pengetahuannya secara konkrit dan mandiri. Menurut Nur (2008), model PBL memberikan peluang kepada siswa untuk mengkonstruksi pengetahuannya yang akan digunakan sebagai pemecahan masalah. Sejalan dengan pendapat tersebut, pengkonstruksian pengetahuan akan mendorong siswa untuk menemukan solusi yang efektif.

Kelemahan pada penelitian ini yaitu tidak memunculkan indikator mana yang paling berpengaruh terhadap kemampuan pemecahan masalah. Hal tersebut dikarenakan keterbatasan waktu untuk menerapkan model $P B L$ pada materi aspek kependudukan. Faktor yang lain yang menyebabkan hal ini adalah kelemahan-kelamahan pada model pembelajaran ini yang sudah diantisipasi tetapi masih menimbulkan masalah. Adapun kelemahan yang sudah diantisipasi oleh guru adalah pembentukan kelompok-kelompok belajar secara heterogen.

\section{KESIMPULAN}

Berdasarkan hasil analisis data dan pembahasan hasil penelitian da-pat disimpulkan bahwa model PBL
Available at http://jurnal.unimed.ac.id/2012/index.php/geo e-ISSN: 2549-7057 | p-ISSN: 2085-8167

berpengaruh signifikan terhadap kemampuan pemecahan masalah geo-grafi SMA. Hal ini dibuktikan dengan hasil perhitungan analisis uji $\mathrm{t}$ menggunakan indenpenden sample $t$ test diperoleh data $\mathrm{p}$ level lebih kecil dari 0,05 $(\mathrm{p}<0,05)$ yaitu 0,00 . Rata-rata skor posttest kelas eksperimen lebih tinggi dibandingkan kelas kontrol. Hal tersebut disebabkan oleh langkah-langkah model $P B L$ yang di dalamnya terdapat teknik-teknik belajar pemecahan masalah dari yang sederhana sampai yang kompleks. Selain temuan utama penelitian ditemukan juga kelebihan dan kelemahan penelitian dengan menggunakan model ini.

\section{DAFTAR PUSTAKA}

Amir, M. Taufik. 2009. Inovasi Pendidikan Melalui Problem Based Learning. Jakarta: Prenada Media Group.

Arends, R.I. 2008. Learning to Teaching. Terjemahan oleh Helly P.S dan Sri Mulyantini S. Yogyakarta: Pustaka Pelajar.

Arvyaty \& Cipto Saputra. 2013. Pengaruh Model Pembelajaran (PBM) Terhadap Kemampuan Penalaran Proporsional Siswa Sekolah Menengah Pertama. Jurnal Pendidikan Matematika, Vol. 4, No. 1, Januari 2013.

Dasna,I Wayan \& Sutrisno. 2005. Model Pembelajaran Problem Based Learning. (Online). http://lubisgrafura.wordpress.com $/ 200$ 7/09/19. Diakses tang-gal 22 Oktober 2013.

Hung, W. etc. 2008. Problem-Based Learning. University of Arizona South, Sierra Vista, Arizona.

Nur, Mohamad. 2008. Model Pembelajaran Berdasarkan Masalah. Surabaya: Unesa Press. 
Minarni, Ani. 2012. Pengaruh Pembelajaran Berbasis Masalah Terhadap Kemam-puan Pemecahan Masalah Matematis. Jurnal Pendidikan, ISBN: 978-979-16353-8-7 10, November 2012 UNY.

Ria, HS. 2009. Pengaruh Metode Pembelajaran STAD vs PBL dan sikap Warga Belajar Paket $B$ di Sanggar Kegiatan Kabupaten Malang Terhadap Kemampuan Pemecahan Masalah dalam Pembelajaran Perkembangan Makhluk Hidup. Tesis tidak diterbitkan. Malang: PPs UM.

Rusman. 2012. Model-Model Pembelajaran Mengembangkan Profesionalisme Guru. Jakarta: PT. Raja Grafindo Persada.

Sudarman. 2007. Problem Based Learning: Suatu Model Pembelajaran untuk Me-ngembangkan dan Meningkatkan Kemampuan Memecahkan Masalah. Jurnal Pendidikan Inovatif, Volume 2, Nomor 2, Maret 2007.
Sumarmi. 2012. Model-Model Pembelajaran Geografi. Malang: Aditya Media Publishing.

Tamri, 2012. Pengaruh Strategi PBL dan kooperatif STAD terhadap Kemampuan Pemecahan Masalah, Berpikir Kritis, Kesadaran Metakognitif dan Penguasaan Konsep Biologi Kelas X SMA Negeri 9 Balikpapan Tahun Ajaran 2011/2012. Tesis tidak diterbitkan. Malang: PPs UM.

Tresnaningsih, Rizqi. 2009. Ekperimentasi Pembelajaran Berbasis Masalah dan Diskusi Kelas terhadap Prestasi Belajar Matematika Siswa Kelas X Ditinjau dai IQ Siswa pada Materi Logika Matematika SMA Negeri Kabupaten Magetan Tahun Ajaran 2009/2010.

(Online). http://RizqiTresnaningsih.blogspot.com . Diakses tanggal 10 November 2013.

Trianto. 2009. Mendesain model Pembelajaran Inovatif Progresif. Jakarta: Kencana Prenada Media Group. 